\title{
Laboratory Diagnostic Approach and Interpretation in Gram-Negative Bacterial Infection: A-Case Report of Sepsis in Secondary Hospital Settings
}

\author{
Adhi Kristianto Sugianli, Ida Parwati \\ Department of Clinical Pathology and Laboratory Medicine, Faculty of Medicine, Universitas Padjadjaran/Dr. Hasan Sadikin General \\ Hospital Bandung, Indonesia. E-mail: adhi_kristianto@unpad.ac.id
}

\begin{abstract}
Gram-Negative Bacteria (GNB) have been widely reported to cause worldwide infections and life-threatening. The high prevalence of drug-resistant GNB causes the treatment of GNB to become difficult. This case report describes a stepwise laboratory approach and interpretation for Gram-negative bacteria infection in sepsis patients. An 84-year-old female patient with a history of congestive heart failure, after three weeks of hospitalization, GNB was proven as the cause of sepsis. Laboratory approach for inflammation (C-reactive protein, procalcitonin) was made and confirmed with a positive culture of several specimens (sputum, urine, and blood). The identification of bacterial-culture revealed as Carbapenem-resistance Klebsiella pneumoniae and Extended-spectrum Beta-lactamases Escherichia coli. This case highlights GNB as a potential agent to worsen the infection (sepsis) and also a useful approach for the detection of multidrug-resistant bacteria, particularly in secondary hospital settings. The application and interpretation of integrated clinical and laboratory criteria may bring out better and effective patient management.
\end{abstract}

Keyword: Drug-resistant microbes, Gram-negative bacteria, sepsis laboratory diagnostic

\section{INTRODUCTION}

Gram-negative bacteria are known to contribute to the great danger for human health, particularly in hospital settings, with reported data shown an increasing prevalence of drug-resistant among Gram-negative bacteria. ${ }^{1}$ Limited antibiotic option as a treatment has become an issue for combating this infection. Therefore, the laboratory approach in Gram-negative infection becomes crucial and plays an important role. ${ }^{2}$ This case reports the stepwise of laboratory approach from the essential initial examination until detection of the presence of extensively-drug resistant Gram-negative bacteria in sepsis and leads to the mortality, as the consequences.

\section{CASE}

A female patient, 84 years old, with main complain of congestive heart failure. The patient was directly admitted to the Intensive Care Unit (ICU) and undergo medical life support. Due to nosocomial screening on the second day of admission, Gram-stain and bacterial sputum culture tests were performed and the bacteria were found to be absent. During hospitalization, the clinical chemistry test was done on this patient and the result was hypoalbuminemia with uremia. The patient showed no clinical improvement after three-weeks of hospitalization. Due to no changes were observed, further clinical evaluation was made. An empirical antibiotic was scheduled for the patient before the bacterial culture was tested. The initial clinical assessment using sepsis-3 guideline (SOFA score), indicated the presence of sepsis. Hospital-acquired Urinary Tract Infection (UTI) and ventilator-associated pneumonia were suspected as the etiology of sepsis. The laboratory results on different dates were summarized in Table 1 .

Complete Blood Count (CBC) is the initial step of the laboratory approach that can be made for suspected infection cases. In Table 1 , the increase of WBC was the first hallmark after one week of hospitalization (result on the day of 6) and interpreted as inflammation. From this result, we used the equation of Neutrophil-to-Lymphocyte Ratio (NLR) to determine whether the inflammation or infection. The NLR value was calculated by dividing the absolute number of neutrophil with the 
absolute number of lymphocyte. ${ }^{3}$ When NLR value is greater than 10, this indicates that it would likely be an infection. ${ }^{4}$ The decrease of hemoglobin level (result on the day of 23 and day of 26) could be used as a marker of the inflammatory response due to chronic or acute process. ${ }^{5}$ Based on the patient comorbidities (age, suspected chronic disease), the history of $C B C$ could be interpreted as anemia normochromic normocytic, which shows an inflammatory response (known as anemia of inflammation). Laboratory result of inflammation biomarker is shown in Table 2.
Procalcitonin (PCT) is a precursor of the hormone calcitonin produced by the parafollicular cells of the thyroid, the neuroendocrine cells of the lung, and the intestine. The previous study has shown that patients with mixed bacteria have significantly higher serum levels of CRP and PCT than in those with viral infection alone. ${ }^{6}$ Therefore, PCT is used as an indicator of antibiotics treatment because the standard is higher in fungal, parasitic, and bacterial than in viral infections. Meanwhile, CRP is a plasma protein synthesized by the hepatocytes. C-reactive protein rises in response to inflammation/cell injury

Table 1. Laboratory result of complete blood count

\begin{tabular}{|c|c|c|c|c|c|c|c|}
\hline \multirow[b]{2}{*}{ Test } & \multicolumn{5}{|c|}{ Result /Date } & \multirow[b]{2}{*}{ Unit } & \multirow[b]{2}{*}{ Reference Range } \\
\hline & $\begin{array}{l}\text { Day } 1 \\
11 / 8\end{array}$ & $\begin{array}{l}\text { Day } 6 \\
17 / 8\end{array}$ & $\begin{array}{l}\text { Day } 12 \\
23 / 8\end{array}$ & $\begin{array}{l}\text { Day } 23 \\
3 / 9\end{array}$ & $\begin{array}{l}\text { Day } 26 \\
6 / 9\end{array}$ & & \\
\hline HGB & 12.1 & - & - & 10.0 & 9.8 & $\mathrm{~g} / \mathrm{dL}$ & $12.0-55.5$ \\
\hline $\mathrm{HCT}$ & 37.6 & - & - & 30.9 & 30 & $\%$ & $35.0-47.0$ \\
\hline $\mathrm{RBC}$ & 3.98 & - & - & 3.39 & 3.28 & $10^{\wedge} 6 / \mathrm{uL}$ & $4.10-5.10$ \\
\hline MCV & 95 & - & - & 91 & 92 & $\mathrm{fL}$ & $80-96$ \\
\hline $\mathrm{MCH}$ & 30 & - & - & 30 & 30 & $\mathrm{pg} / \mathrm{mL}$ & $28-33$ \\
\hline $\mathrm{MCHC}$ & 32 & - & - & 32 & 33 & $\%$ & $33-36$ \\
\hline RDW & 16 & - & - & 16 & 17 & $\%$ & $11-16$ \\
\hline WBC & 7.58 & 14.01 & 11.55 & 9.93 & 9.87 & $10^{\wedge} 3 / \mathrm{uL}$ & $4.4-11.0$ \\
\hline PLT & 261 & - & - & 190 & 162 & $10^{\wedge} 3 / \mathrm{uL}$ & $150-450$ \\
\hline \multicolumn{8}{|l|}{ Diff count } \\
\hline BAS\% & 0 & 0 & 0 & 0 & 0 & $\%$ & $0-1$ \\
\hline EOS\% & 2 & 1 & 1 & 1 & 1 & $\%$ & $2-6$ \\
\hline SEG\% & 60 & 86 & 87 & 78 & 87 & $\%$ & $50-70$ \\
\hline LYM\% & 30 & 8 & 6 & 16 & 8 & $\%$ & $20-40$ \\
\hline MONO\% & 8 & 4 & 6 & 5 & 4 & $\%$ & $2-10$ \\
\hline
\end{tabular}

Abbrev: HGB, hemoglobin; HCT, hematocrit; RBC, Red Blood Cell; MCV, Mean Corpuscular Volume; MCH, Mean Corpuscular Hemoglobin; MCHC, Mean Corpuscular Hemoglobin Concentration; RDW, Red Cell Distribution Width; WBC, White Blood Cell; PLT, platelet; BAS, basophil; EOS, eosinophil; SEG, segmented neutrophil; LYM, lymphocyte; MONO, monocyte; Day, refer to the day of hospitalization; Bold letter, refers to abnormal value compared to a reference range.

Table 2. Laboratory result of inflammation biomarker

\begin{tabular}{|c|c|c|c|c|}
\hline \multirow[b]{2}{*}{ Test } & \multicolumn{2}{|c|}{ Result /D ate } & \multirow[b]{2}{*}{ Unit } & \multirow[b]{2}{*}{ Reference Range } \\
\hline & $\begin{array}{l}\text { Day } 2 \\
12 / 8\end{array}$ & $\begin{array}{l}\text { Day } 26 \\
6 / 9\end{array}$ & & \\
\hline Procalcitonin & 0.26 & 1.36 & $\mathrm{ng} / \mathrm{mL}$ & $\begin{array}{l}\text { Normal: }<0.5 \\
\text { Borderline: } 0.5-2 \\
\text { Sepsis: }>2\end{array}$ \\
\hline CRP quantitative & - & 52.60 & $\mathrm{mg} / \mathrm{dL}$ & $<5.0$ \\
\hline
\end{tabular}

Abbrev: CRP, C-Reactive Protein; Day, refer to the day of hospitalization. The bold letter refers to abnormal value compared to the reference range 
and various diseases by pathogens. Increasing in the CRP level is due to cell-membrane-binding capability, which occurs through its attachment to the phosphocholine in exposed cell membranes during cell injury, and the phosphocholine in the polysaccharides of pathogens present in the infections. ${ }^{6,7}$ Based on Table 2, the increasing of PCT and CRP level on the day of 26, indicated a clinical suspicion of disease starting antibiotic treatment. This is also confirmed with the finding of microbes on sputum and urine specimens after three days, which provide a shred of evidence on sepsis. As a part of getting confirmation of the presence of UTI, urinalysis was performed, as shown in Table 3.

The novel advanced method of urinalysis is feeding more information compared with the

Table 3. Laboratory result of urinalysis with flow cytometry method

\begin{tabular}{|c|c|c|c|}
\hline \multirow[b]{2}{*}{ Test } & Result/Date & \multirow[b]{2}{*}{ Unit } & \multirow[b]{2}{*}{ Reference Range } \\
\hline & $\begin{array}{l}\text { Day } 26 \\
6 / 9\end{array}$ & & \\
\hline \multicolumn{4}{|l|}{ Chemical test } \\
\hline Color & Yellow & - & Yellow \\
\hline Turbidity & Turbid & - & Clear \\
\hline Specific gravity & 1.009 & - & $1.005-1.035$ \\
\hline $\mathrm{pH}$ & 5.0 & - & $4.6-8.0$ \\
\hline Protein & 30 & $\mathrm{mg} / \mathrm{dL}$ & Negative \\
\hline Glucose & Negative & $\mathrm{mg} / \mathrm{dL}$ & Negative \\
\hline Bilirubin & Negative & $\mathrm{mg} / \mathrm{dL}$ & Negative \\
\hline Ketone & Negative & $\mathrm{mg} / \mathrm{dL}$ & Negative \\
\hline Nitrite & Negative & - & Negative \\
\hline Leucocyte esterase & 500 & Leu/uL & Negative \\
\hline Blood & 0.5 & $\mathrm{mg} / \mathrm{dL}$ & Negative \\
\hline Urobilinogen & Normal & - & Normal \\
\hline \multicolumn{4}{|l|}{ Sediment test } \\
\hline Red blood cell & 336.2 & $/ \mathrm{uL}$ & $<=10.2$ \\
\hline White blood cell & 5714.4 & $/ \mathrm{uL}$ & $<=10.4$ \\
\hline Epithelial cell & 63.7 & $/ \mathrm{uL}$ & $<=13$ \\
\hline Cast & 2.57 & $/ \mathrm{uL}$ & $<1.6$ \\
\hline Bacteria & 12385.6 & $/ \mathrm{uL}$ & $\mathrm{m}:<=26 ; \mathrm{f}:<=99$ \\
\hline
\end{tabular}

Abbrev: Day, refer to the day of hospitalization; $m$, male; f, female; Bold letter, refer to abnormal value compared to the reference range
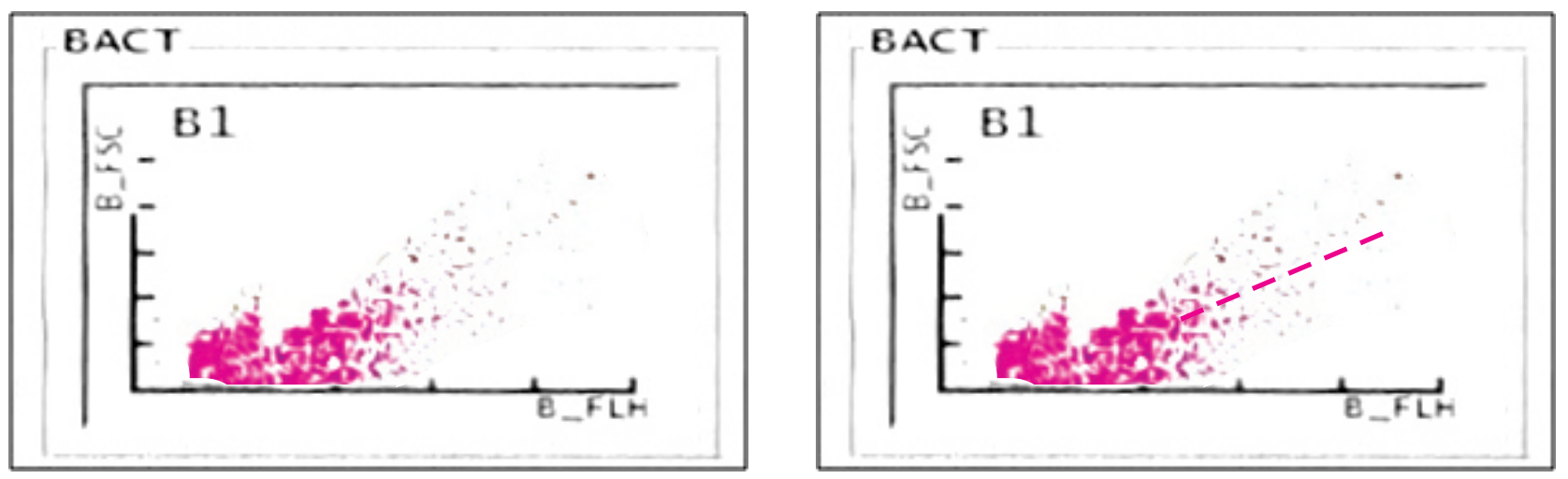

Figure 1. The Bacterial scattergram result of UFC (A). The 30-degree angle (red-dashed line) will determine the distribution of bacteria; lies below the line indicate bacilli/rod organisms (Gram-negative) 
previous conventional method. The usefulness of Urine Flow Cytometry (UFC), particularly for sediment tests, is giving quantitative measurement and also scattergram pattern, which provides a lot of information, such as type of bacteria, the morphology of red blood cells. The patient was suspected of having a nosocomial urinary tract infection on the third week of her hospitalization. The routine urinalysis reveals an increase in turbidity, positive leukocyte esterase with the presence of a

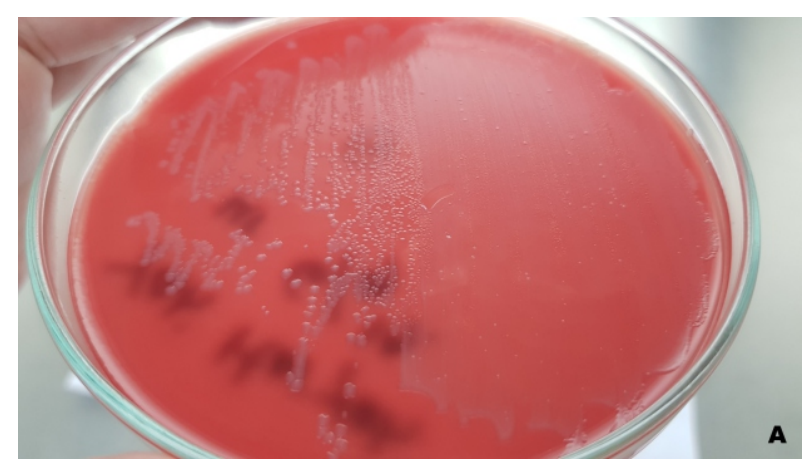

high number of $\mathrm{WBC}, \mathrm{RBC}$. These indicate an inflammatory response due to bacterial infection. The bacterial scattergram is the graph of bacteria distribution from the examined urine using UFC (Figure 1).

The advanced method of UFC allows us to access the presumptive typical of bacteria by determining the pattern of the graph. From the scattergram (Figure 1A), the B_FSC indicates the particle size and B_FLH suggested the level of particle nucleus

Figure 2. Urine colony count on the blood agar plate. The colonies grow on all of the blood agar plates, which reveal $10^{\wedge} 5 \mathrm{CFU} / \mathrm{mL}(\mathrm{A})$. The morphology of growth colonies shows grey-white color, clear-edge shape, raised, and non-mucoid (B)

Table 4. Laboratory result of microbiology identification and susceptibility testing

\begin{tabular}{|c|c|c|c|c|}
\hline \multirow[b]{2}{*}{ Test } & \multicolumn{3}{|c|}{ Result/Date } & \\
\hline & $\begin{array}{l}\text { Day } 27 \\
25 / 8\end{array}$ & $\begin{array}{l}\text { Day } 29 \\
9 / 9\end{array}$ & $\begin{array}{l}\text { Day } 30 \\
10 / 9\end{array}$ & \\
\hline \multicolumn{5}{|l|}{ Identification test } \\
\hline Specimen & Sputum & Urine Eco & Blood & \\
\hline Isolate & Kpn & $\begin{array}{l}\text { Colony count: } \\
>100.000 \mathrm{CFU} / \mathrm{mL}\end{array}$ & Kpn & Psa \\
\hline \multicolumn{5}{|l|}{ Susceptibility test } \\
\hline Ceftriaxone & $\mathbf{R}$ & $\mathbf{R}$ & $\mathbf{R}$ & - \\
\hline Gentamycin & $\mathrm{R}$ & $\mathrm{R}$ & $\mathrm{R}$ & $\mathrm{S}$ \\
\hline Amikacin & $\mathrm{R}$ & $\mathrm{S}$ & $\mathrm{R}$ & $\mathrm{S}$ \\
\hline Ampicillin-Sulbactam & $\mathrm{R}$ & $\mathrm{R}$ & $\mathrm{R}$ & - \\
\hline Piperacillin/Tazobactam & $\mathrm{R}$ & $\mathrm{S}$ & $\mathrm{R}$ & $\mathrm{S}$ \\
\hline Ceftazidime & $\mathbf{R}$ & $\mathbf{R}$ & $\mathbf{R}$ & $\mathrm{S}$ \\
\hline Cefepime & $\mathbf{R}$ & $\mathbf{R}$ & $\mathbf{R}$ & $\mathrm{S}$ \\
\hline Co-trimoxazole & $\mathrm{S}$ & $\mathrm{S}$ & $\mathrm{S}$ & - \\
\hline Tigecycline & $S$ & $S$ & $\mathrm{~S}$ & $\mathrm{R}$ \\
\hline Nitrofurantoin & $\mathrm{R}$ & $S$ & $\mathrm{R}$ & - \\
\hline Aztreonam & $\mathbf{R}$ & $\mathbf{R}$ & $\mathbf{R}$ & $S$ \\
\hline Ertapenem & $\mathbf{R}$ & $\mathrm{S}$ & $\mathbf{R}$ & - \\
\hline Meropenem & $\mathbf{R}$ & $S$ & $\mathbf{R}$ & $\mathrm{S}$ \\
\hline Ciprofloxacin & $\mathrm{R}$ & $S$ & $\mathrm{R}$ & $\mathrm{S}$ \\
\hline Fosfomycin & - & I & - & - \\
\hline
\end{tabular}

Abbrev: Kpn, Klebsiella pneumoniae; Eco, Escherichia coli; Psa, Pseudomonas aeruginosa; Day, refer to the day of hospitalization; (-), not tested; Bold letter, refer to abnormal value compared to the reference range 
staining (high sensitivity). Bacterial nucleic acids were specifically stained with polymethine dye. The distribution of bacteria from the scattergram lies below the 30-degree angle (low-angle), which highly indicates for bacilli/rod microbe (Figure 1B). ${ }^{8,9}$ This result is confirmed by the microbes finding, as shown in Figure 2. The Gram-stain of growth colonies was determined as Gram-negative-bacilli/rod organisms. Colony's growth in selective media (MacConkey agar) shown pink color colonies with lactose-fermenter reactions, which strongly indicated Gram-negative bacteria (picture is not shown).

The organism identified from sputum and blood is Klebsiella pneumoniae, with similar antimicrobial drug resistance: ESBL and Carbapenem Resistant Klebsiella pneumoniae (CR-Kp) (Table 4). Klebsiella pneumoniae fulfills all the criteria of the true infection, which falls under these conditions: the same organism grows in more than one specimen within 48 hours; when different isolates of one species show the same biotypes and antimicrobial-susceptibility profile. ${ }^{10}$ In the urine specimen, the organism was determined as Escherichia coli, with ESBL. With the colony count of more than $100.000 \mathrm{CFU} / \mathrm{mL}$, nosocomial UTI is also likely to put a definitive diagnosis. The microbiology finding from various specimens confirms the systemic bacterial infection of Gram-negative and highly indicative of sepsis. Therefore, Klebsiella pneumoniae is categorized as Extensively Drug-Resistant Organisms (XDRO) and potentially contributes to septic shock. ${ }^{2,11}$

\section{DISCUSSION}

The researchers generated a stepwise laboratory diagnostic approach of Gram-negative bacteria infection in nosocomial sepsis patients. In this case, we highlighted three important laboratory aspects, which contribute to sepsis: complete blood count, an early indicator of inflammation and sepsis; the additional value of urinalysis in UTI-related to sepsis; and susceptibility testing to detect the presence of a multidrug-resistant organism.

Sepsis is defined as a life-threatening organ dysfunction caused by a dysregulated host response to infection. Using the new consensus of sepsis, organ dysfunction can be represented by an increase in the Sequential [Sepsis-related] Organ Failure Assessment (SOFA) score of two points or more, which is associated with in-hospital mortality higher than $10 \%$. Septic shock should be defined as a subset of sepsis, particularly profound circulatory, cellular, and metabolic abnormalities, which are associated with a higher risk of mortality than with sepsis alone. ${ }^{12}$ In this case, the hematology parameter is showing inflammation and also increasing of CRP, $P C T$, which indicated sepsis is more likely to be suspected.

This case also reveals evidence of anemia of inflammation and renal failure. According to the National Health and Nutritional Examination Study (NHANES III), anemia of inflammation is defined as a low serum iron level without evidence of little iron stores, or inappropriately has low levels of erythropoietin, or elevated measures of inflammatory markers, such as C-reactive protein. Interleukin-6 (IL-6) and interleukin-1 $1 \beta$ (IL-1 $\beta$ ) were key cytokines that mediate the effects of inflammation on the development of erythrocyte. Both cytokines promote the expression of hepcidin. Hepcidin is a short, cysteine-rich peptide hormone that regulates the intestinal absorption of iron.

Human hepatocytes secrete the hepcidin as a response to iron overload or inflammation. Hepcidin binds to ferroportin on the surface of macrophages, resulting in the internalization and degradation of both proteins and the sequestration of iron in macrophages. In addition, cytokines also have a certain effect on iron metabolism: diminish erythropoietin synthesis; impair the differentiation of erythroid progenitors, and shorten the lifespan of mature red blood cells. The presence of renal failure also exacerbates the effects of inflammation. The history of uremia, in this case, is associated with the reducing levels of albumin, increasing levels of nitric oxide, and changing in the levels of erythrocyte membrane proteins. These membrane proteins promote the accumulation of reactive oxygen species and the oxidation of erythrocyte membrane proteins. Those alterations could accelerate erythrocyte destruction and tissue injury. ${ }^{5}$

Urinary tract infections are the most common infections in the hospital and community setting. The gold standard to diagnose UTI is testing using bacterial culture, although it is known as time-consuming and costly. ${ }^{13}$ The UFC can identify particles in urine by scattering and fluorescence after staining. The feasibility of using UFC to reduce the number of bacterial culture test, by screening the urine samples has been analyzed in the previous study. ${ }^{14-17}$ Bacterial morphology is detected using the forward (cell volume) and side scatters fluorescence, 
by emitting its laser beam to produce a scattergram. It was observed that Gram-negative resulted in a different scatter pattern than Gram-positive bacteria. In general, rods/bacilli bacteria will be divided into two independent entities once they achieve a specific size of the cell growth. The nucleic acid content of the particles tends to be constant while the scattergram tends to have a fairly well-defined distribution (convergent distribution). On the other hand, cocci bacteria divide irregularly and multiply along two or three planes to form grape-like irregular clusters. Thus, the nucleic acid content will increase and their distribution on the scattergram is expected to show wider dispersion. Classification of the bacterial morphology from scattergram pattern as defined in the previous study, using a straight line that was drawn through the middle of the obtained scatter cloud (30-degree-angle): the angle with the $\mathrm{x}$-axis determines if the bacteria found are classified as rods/bacilli (below 30-degree-angle) or cocci/ mixed (above 30-degree-angle). ${ }^{8,9,14-18}$

The previous study has shown the sensitivity and specificity of the cut-off of both bacterial count and WBC count to improve the diagnostic value of UTI. Researchers have described previous finding for the cut-off value of bacterial and WBC count. Using the combination of bacterial count $\geq 277.4$ bacteria/uL, WBC count $\geq 300.7$ cells/uL, and positive UTI criterion, the results achieved a specificity of $87.5 \%$ and a positive predictive value of $96.6 \%{ }^{19}$ Within this case, it is shown that the combination quantitative of WBC and the bacterial count can be applied, in concordance with bacterial morphology classified as rods/bacilli organism. The result was proven with the culture result of Escherichia coli. In the B1 UFC scattergram (Figure 1), there are scattered clouds that were observed in the cocci/mixed area. Previous antibiotic treatment and the development of resistance may affect the bacterial distribution pattern due to the filament formation in Gram-negative bacilli as mentioned in the previous study. 8, $^{8182}$

Klebsiella pneumoniae is a Gram-negative pathogenic bacteria and part of the Enterobacteriaceae family. They are comprised of other common pathogens such as Escherichia coli, Yersinia spp., Salmonella spp., and Shigella spp. Klebsiella pneumoniae causes serious infections, including pneumonia, UTI, and bloodstream infection. ${ }^{21}$ Klebsiella pneumoniae virulence factors are encoded by genes in both the core and accessory genomes. Established virulence factors in Klebsiella pneumoniae include capsule, lipopolysaccharide (LPS), siderophores, and pili. The LPS, also termed endotoxin, is a major component decorating the outer membrane of Gram-negative bacteria.

The LPS is widely recognized as the most potent mediator of septic shock. ${ }^{2}$ In this case, two types of Klebsiella pneumoniae is categorized as extensively multidrug-resistant organisms, they are Extended-Spectrum Beta-Lactamases (ESBL) and Carbapenem-Resistant Klebsiella pneumoniae (CR-Kp). The Extended-Spectrum Beta-Lactamases are plasmid-based resistance mechanisms that are part of the accessory genome, meanwhile, Carbapenem-resistance in Klebsiella pneumoniae can be mediated in part through up-regulation of

\begin{tabular}{|c|c|c|c|}
\hline \multicolumn{2}{|c|}{ MDRO } & \multicolumn{2}{|r|}{ XDRO } \\
\hline Definition & $\begin{array}{l}\text { Antimicrobial } \\
\text { groups }\end{array}$ & Definition & Antimicrobial groups \\
\hline \multicolumn{4}{|c|}{ Enterobacteriaceae } \\
\hline \multirow{6}{*}{$\begin{array}{l}\text { Resistance } \\
\text { to THREE } \\
\text { OR FOUR } \\
\text { of the SIX } \\
\text { antimicrobial } \\
\text { groups }\end{array}$} & $\begin{array}{l}\text { Tobramycin OR }{ }^{\mathrm{a}} \\
\text { gentamicin } \mathrm{b}\end{array}$ & \multirow{6}{*}{$\begin{array}{l}\text { Resistance } \\
\text { to FIVE OR } \\
\text { Six of the } \\
\text { antimicrobial } \\
\text { groups }\end{array}$} & Tobramycin OR gentamicin \\
\hline & $\begin{array}{l}\text { Piperacillin- } \\
\text { tazobactam }\end{array}$ & & Piperacillin-tazobactam \\
\hline & $\begin{array}{l}\text { Imipenem OR } \\
\text { meropenem }{ }^{c}\end{array}$ & & Imipenem OR meropenem \\
\hline & $\begin{array}{l}\text { Cefotaxime OR } \\
\text { ceftriaxone OR } \\
\text { ceftazidine }\end{array}$ & & $\begin{array}{l}\text { Cefotaxime OR ceftriaxone } \\
\text { OR ceftazidine }\end{array}$ \\
\hline & Ciprofloxacin & & Ciprofloxacin \\
\hline & $\begin{array}{l}\text { Trimethoprim- } \\
\text { sulfamethoxazole }\end{array}$ & & $\begin{array}{l}\text { Trimethoprim- } \\
\text { sulfamethoxazole }\end{array}$ \\
\hline
\end{tabular}

Figure 3. Definitions for the determination of MDRO/XDRO in select organisms. The term 'OR' should be interpreted as follows: if an isolate is resistant to either antimicrobial agent listed, it should be considered resistant to that criterion for these definitions. ${ }^{11}$ Abbrev: MDRO, Multidrug-Resistant Organisms; XDRO, Extensively Drug-Resistant Organisms 


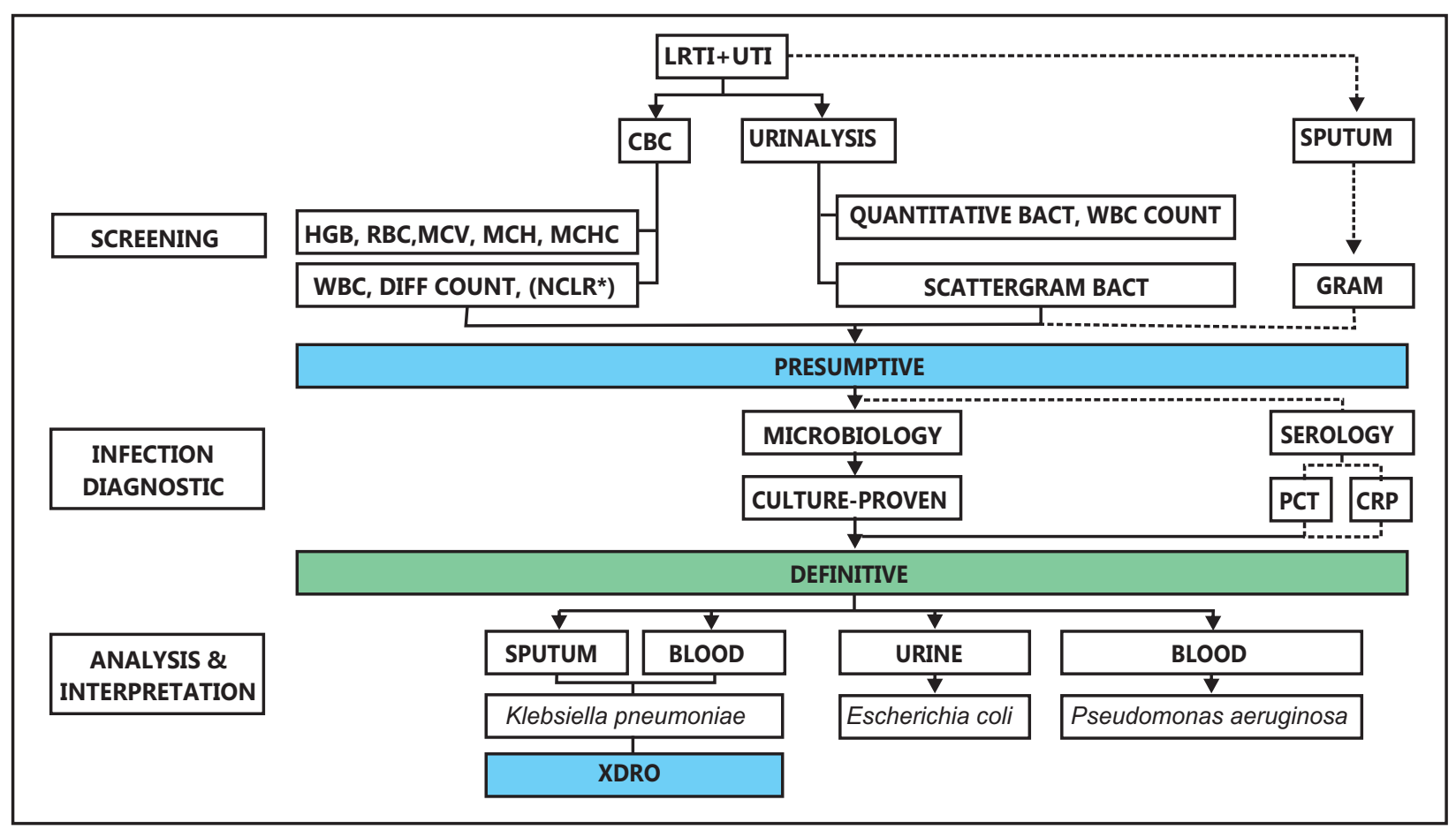

Figure 4. Summarized laboratory approach modalities in Gram-negative bacteria infection

efflux pumps; alteration of outer membrane porins in the core genome; hyperproduction of ESBL enzymes or AmpC $\beta$-lactamases in the accessory genome and resistance is through plasmid-mediated carbapenemases. ${ }^{2,22}$ The definition of XDRO of Klebsiella pneumoniae is made according to a recommendation from the Canadian Public Health Laboratory Network and the Canadian Association of Clinical Microbiology and Infectious Diseases (Figure 3). ${ }^{11}$ The susceptibility result of this case shows a resistance profile to Gentamicin, Piperacillin-tazobactam, Meropenem, Ceftriaxone, Ceftazidime, and Ciprofloxacin.

\section{CONCLUSION}

This case has shown the use of multiple modalities in the screening and detection of Gram-negative bacteria as the cause of sepsis in old-female-patient. Routine hematology and urinalysis are still a-useful-early before stepping into more advanced diagnostic instruments (Figure 4). Therefore, care and understanding of diagnostic modalities should be taken, particularly in establishing the diagnosis of infectious disease to give better patient management.

\section{REFERENCE}

1. Heesterbeek DAC, Martin NI, Velthuizen A, Duijst M, Ruyken M, Wubbolts R, et al. Complement-dependent outer membrane perturbation sensitizes Gram-negative bacteria to Gram-positive specific antibiotics. Sci Rep, 2019; 9(1): 3074.

2. Martin RM, Bachman MA. Colonization, infection, and the accessory genome of Klebsiella pneumoniae. Front Cell Infect Microbiol, 2018; 8: 4.

3. Forget $P$, Khalifa C, Defour J-P, Latinne D, Van Pel M-C, De Kock $M$. What is the normal value of the neutrophil-to-lymphocyte ratio?. BMC Res Notes, 2017; 10(1): 12.

4. Ljungström $L$, Pernestig A-K, Jacobsson $G$, Andersson $R$, Usener B, Tilevik D. Diagnostic accuracy of procalcitonin, neutrophil-lymphocyte count ratio, C-reactive protein, and lactate in patients with suspected bacterial sepsis. Azevedo LCP, editor. PLos One, 2017; 12(7): e0181704.

5. Fraenkel PG. Anemia of inflammation. Med Clin North Am, 2017; 101(2): 285-96.

6. Onyenekwu CP, Okwundu CI, Ochodo EA. Procalcitonin, C-reactive protein, and presepsin for the diagnosis of sepsis in adults and children. Cochrane Emergency and Critical Care Group, editor. Cochrane Database Syst Rev. 2017. Available from: http://doi.wiley.com/10.1002/14651858.CD012627 (accessed September 5, 2019) 
7. Korean Shock Society (KoSS) Investigators, Ryoo SM, Han KS, Ahn S, Shin TG, Hwang SY, et al. The usefulness of $\mathrm{C}$-reactive protein and procalcitonin to predict prognosis in septic shock patients: A multicenter prospective registry-based observational study. Sci Rep. 2019; 9(1): 6579.

8. Yamaguti I, Uki N, Ikeda H, Kawasaki S, Nagasawa Z, et al. About the usefulness of the urinary tract infection screening using UX-2000. Sysmex J Int, 2013; 23(1): 6.

9. Yasutake $Y$, Higuchi M, Oda S, Tamura Y, Shimadu T, et al. Comparisons of the bact scattergram pattern by fully automated integrated urine analyzer UX-2000 and microscopic examination results using Gram stain. Sysmex J Int, 2013; 23(1): 10.

10. Vandepitte J, World Health Organization, editors. Basic laboratory procedures in clinical bacteriology. $2^{\text {nd }}$ Ed., Geneva, World Health Organization, 2003; 167.

11. German G, Gilmour M, Tipples G, Adam H, Almohri H, et al. Canadian recommendations for laboratory interpretation of multiple or extensive drug resistance in clinical isolates of Enterobacteriaceae, Acinetobacter species and Pseudomonas aeruginosa. Can Commun Dis Rep, 2018; 44(01): 29-34.

12. Singer $M$, Deutschman CS, Seymour CW, Shankar-Hari $M$, Annane $D$, et al. The third international consensus definitions for sepsis and septic shock (sepsis-3). JAMA, 2016; 315(8): 801.

13. Ginting F, Sugianli AK, Kusumawati RL, Parwati I, de Jong $\mathrm{MD}$, et al. Predictive value of the urinary dipstick test in the management of patients with urinary tract infection-associated symptoms in primary care in Indonesia: A cross-sectional study. BMJ Open, 2018; 8(8): e023051.

14. De Rosa R, Grosso S, Lorenzi G, Bruschetta G, Camporese A. Evaluation of the new Sysmex UF-5000 fluorescence flow cytometry analyser for ruling out bacterial urinary tract infection and for prediction of
Gram-negative bacteria in urine cultures. Clin Chim Acta, 2018; 484: 171-8.

15. Yang C-C, Chang S-J, Yang SS-D, Lin C-D, Peng C-H. Rapid diagnosis of uncomplicated urinary tract infection with laser flow cytometry. Urol Sci, 2016; 27(3): 135-9.

16. Jefferson B, Mendoza VVA. Predict urinary tract infection and to estimate causative bacterial class in a Philippine Subspecialty Hospital. J Nephrol Ther, 2015; 5: 2.

17. Geerts N, Jansz AR, Boonen KJM, Wijn RPWF, Koldewijn EL, et al. Urine flow cytometry can rule out urinary tract infection, but cannot identify bacterial morphologies correctly. Clin Chim Acta, 2015; 448: 86-90.

18. Ozawa H, Yajima N, Kobayashi H. Estimation of the causative bacterial group from bacterial scattergrams of the fully automated urine particle analyzer UF-1000i. Sysmex J Int, 2012; 22(1): 6.

19. Sugianli AK, Parwati I, Rachmayati S. Combination of quantitative bacterial and WBC count from urine flow cytometry to estimate the success of urine culture in symptomatic urinary tract infections. Malays J Microbiol, 2017; 13: 7.

20. Sánchez-García JM, Sorlózano-Puerto A, Navarro-Marí JM, Gutiérrez Fernández J. Evolution of the antibiotic-resistance of microorganisms causing urinary tract infections: A 4-year epidemiological surveillance study in a hospital population. Rev Clínica Esp Engl Ed, 2019; 219(3): 116-23.

21. Sugianli AK, Ginting F, Kusumawati RL, Pranggono EH, Pasaribu AP, et al. Antimicrobial resistance in uropathogens and appropriateness of empirical treatment: A population-based surveillance study in Indonesia. J Antimicrob Chemother, 2017; 72: 1469-77.

22. San Millan A. Evolution of plasmid-mediated antibiotic resistance in the clinical context. Trends Microbiol, 2018; 26(12): 978-85. 